\title{
Perbedan Terapi Madu Dan Multi Vitamin Terhadap Kadar Hemoglobin, Albumin Dan Status Nutrisi Pada Anak Balita
}

\author{
Meri Neherta \\ ${ }^{a}$ Program Studi Ilmu Keperawatan Universitas Andalas \\ Email :meri_neherta@yahoo.com
}

\begin{abstract}
Intake good nutrition plays an important role in achieving optimal body growth. Optimal body growth also includes growth in the brain that determine someone's intelligence. Factors that are most visible in the community is the lack of a mother's knowledge about the nutritional intake of children that must be met at the time of growth. Design research is the research design simple experiments. Research was conducted from May to September 2011 in work areas Nanggalo Health Center, Padang. The population in this research is all the toddlers who are in work areas of Nanggalo Health Center Padang. Number of samples 60 people, 30 people got the intervention therapy of multivitamins and 30 more people got honey therapy given for 30 days. After the Friedman test is done, both groups have the same significance level $(P<0.05)$, this means there is no difference in group 1 to group 2. To find out which group has the distinction of being the most powerful, must be done Wilcoxon test. The conclusions of this research was obtained that the therapeutic effect Multivitamin better than honey therapy + vitamin B complex on levels of hemoglobin, albumin and nutritional status $(w / U)$ in toddlers who are in work areas of Nanggalo Health Center Padang 2011. It is recommended to health workers to provide counseling to the community so that the toddler was given the multi vitamin to supplement the needs for growth and development of toddlers because it is readily available at prices affordable by the public.
\end{abstract}

Keywords : nutritional status, hemoglobin, Albumin, multivitamin, honey

\begin{abstract}
Abstrak : Intake gizi yang baik berperan penting dalam mencapai pertumbuhan badan yang optimal. Pertumbuhan badan yang optimal ini mencakup pula pertumbuhan otak yang sangat menentukan kecerdasan seseorang. Faktor yang paling terlihat pada lingkungan masyarakat adalah kurangnya pengetahuan ibu mengenai zat gizi yang harus dipenuhi anak pada masa pertumbuhan. Rancangan penelitian adalah eksperimen sederhana. Penelitian dilakukan dari bulan Mei sampai September 2011 di Wilayah Kerja Puskesma Nanggalo, Kota Padang. Populasi dalam penelitian ini adalah Semua Balita yang ada di Wilayah Kerja Puskesmas Nanggalo Kota Padang. Jumlah sampel 60 orang, 30 orang mendapat intervensi terapi multi vitamin dan 30 orang lagi mendapat terapi madu yang diberikan selama 30 hari. Untuk mengetahui kelompok mana yang mempunayi perbedaan yang paling kuat, harus dilakukan uji Wilcoxon. Kesimpulan dari penelitian adalah efek terapi Multivitamin lebih baik dari terapi madu + vit B Complek terhadap kadar hemoglobin, albumin dan status nutrisi ( BB/U ) pada balita diwilayah kerja Puskesmas Nanggalo Kota Padang Tahun 2011. Disarankan kepada petugas kesehatan untuk memberikan penyuluhan kepada masyarakat agar balita diberi minum multi vitamin guna melengkapi kebutuhan untuk tumbang balitanya karena mudah didapat dengan harga yang terjangkau oleh masyarakat.
\end{abstract}

Kata kunci : Status nutrisi, hemoglobin, Albumin, Multivitamin, Madu,

Konsumsi gizi yang baik dan cukup seringkali tidak bisa dipenuhi oleh seorang anak karena faktor eksternal maupun internal. Faktor eksternal menyangkut keterbatasan ekonomi keluarga sehingga uang yang tersedia tidak cukup untuk 
membeli makanan. Sedangkan faktor internal adalah faktor yang terdapat didalam diri anak yang secara psikologis muncul sebagai problema makan pada anak ( Wong , 2009 ). Anak balita memang sudah bisa makan apa saja seperti halnya orang dewasa. Tetapi balitapun bisa menolak bila makanan yang disajikan tidak memenuhi selera mereka. Oleh karena itu sebagai orang tua harus berlaku demokratis untuk sekali-kali menghidangkan makanan yang memang menjadi kegemaran si anak.

Intake gizi yang baik berperan penting di dalam mencapai pertumbuhan badan yang optimal. Dan pertumbuhan badan yang optimal ini mencakup pula pertumbuhan otak yang sangat menentukan kecerdasan seseorang. Faktor yang paling terlihat pada lingkungan masyarakat adalah kurangnya pengetahuan ibu mengenai gizigizi yang harus dipenuhi anak pada masa pertumbuhan. Ibu biasanya suka membelikan makanan yang enak kepada anaknya tanpa tahu apakah makanan tersebut mengandung gizi-gizi yang cukup atau tidak, dan tidak mengimbanginya dengan makanan sehat yang mengandung banyak gizi (Golden M.H.N., 2001)

Makan sehat dahn merngandung gizi yang cukup sangat penting dalam pertumbuhan anak. Karenanya, kecukupan nutrisi memiliki peran penting, baik dalam pertumbuhan fisik atau pun kognitif. Picky eater adalah istilah yang diberikan pada anak yang susah makan, atau hanya suka makanan jenis tertentu saja. Kesulitan makan pada anak dapat menyebabkan anak akan kekurangan mikro dan makronutrien yang pada akhirnya menyebabkan penurunan kualitas anak. (Almatsier, 2001.)

Kualitas seorang anak dapat dinilai dari proses tumbuh kembang. Proses tumbuh kembang merupakan hasil interaksi faktor genetik dan faktor lingkungan. Faktor genetik/keturunan adalah faktor yang berhubungan dengan gen yang berasal dari ayah dan ibu, sedangkan faktor lingkungan meliputi lingkungan biologis, fisik, psikologis, dan sosial. Pertumbuhan dan perkembangan mengalami peningkatan yang pesat pada usia dini, yaitu dari 0 sampai 5 tahun. Masa ini sering juga disebut sebagai fase "Golden Age". Golden age merupakan masa yang sangat penting untuk memperhatikan tumbuh kembang anak secara cermat agar sedini mungkin dapat terdeteksi apabila terjadi kelainan ( Wong, 2004 ).

Pemantauan kelainan tumbuh kembang anak meliputi pemantauan dari aspek fisik, psikologi dan sosial. Pemantauan tersebut harus dilakukan secara teratur dan berkesinambungan. Pemantauan dari aspek fisk bisa dilakukan dengan melakukan pemeriksaan anthropometri dan laboratorium. Pemeriksaan anthropometri sangat mendukung untuk mengetahui secara dini apakah anak mengalami gangguan pertumbuhan. Pemeriksaan antropometri yang paling sederhana bisa dilakukan dengan melakukan pengukuran berat badan terhadap umur ( BB/U ). Dari hasil BB/ U ini dapat diketahui bahwa seorang anak mengalami gangguan nutrisi akut ( Sutjiningsih, 2009 ).

Pemeriksaan laboratorium akan sangat menunjang apakah anak balita mengalami gangguan gizi akut. Deteksi dini dari pemeriksaan laboratorium antara lain melalui pemeriksaan hemoglobin dan albumin. Pada pemerikasaan hemoglobin akan didapatkan nilai kadar hemoglobinnya $<11 \mathrm{mg} \%$. Fungsi utama dari hemoglobin adalah mengangkut oksigen yang diperlukan oleh sel-sel di seluruh tubuh. Darah juga menyuplai jaringan tubuh dengan nutrisi, mengangkut zat-zat sisa metabolisme, dan mengandung berbagai bahan penyusun sistem imun yang bertujuan mempertahankan tubuh dari berbagai penyakit (Alimul Hidayat, 2005 ),

Untuk mempertahankan tubuh dari berbagai macam penyakit, perlu dilakukan pemeriksaan darah dilaboratorium. Pada pemeriksaan hemoglobin akan didapat kadar hemoglobin darah yang rendah. Selain pemeriksaan hemoglobin yang rendah, pada pemeriksaan albuminpun akan didapatkan nilai albumin < dari 3,5 Albumin adalah salah satu jenis protein darah yang 
diproduksi di hati (hepar). Albumin merupakan jenis Protein terbanyak dalam plasma mencapai kadar $60 \%$. Manfaatnya untuk membantu jaringan sel baru. Albumin ini digunakan untuk mempercepat pemulihan jaringan sel tubuh yang terbelah / rusak. Albumin juga berperan mengikat Obat-obatan serta Logam berat yang tidak mudah larut dalam darah. Albumin memiliki sejumlah fungsi. Salah satu fungsi protein adalah mengatur tekanan osmotik di dalam darah. Albumin menjaga keberadaan air dalam plasma darah sehingga bisa mempertahanan volume darah. Bila jumlah albumin turun maka akan terjadi penimbunan cairan dalam jaringan (edema) misalnya bengkak di kedua kaki. Atau bisa terjadi penimbunan cairan dalam rongga tubuh misalnya di perut yang disebut ascites ( Puone T, Sanders D, Chopra M , 2001. Puone T, Sanders D, Chopra M , 2001).

Puskesmas Nanggalo adalah salah satu Puskesmas dari 11 Puskesmas yang ada di kota Padang. Jumlah Balita pada puskesmas ini merupakan jumlah balita terbanyak dari Puskesmas lainnya yang ada di Kota Padang. Dari data yang didapat diketahui bahwa jumlah balita adalah sekitar +3497 orang. Dari yang ditimbang sebanyak 1083 orang, yang berat badannya naik hanya 492 orang, bawah garis merah ( BGM ) 59 orang ( $5,45 \%$ ) (Dinkes Kota Padang tahun 2010 ).

Dari survei awal yang dilakukan pada saat posyandu bahwa pada kader dan 5 orang tua balita bahwa, berat badan anaknya tidak sesuai dengan umur anak disebabkan oleh anak sulit makan. Menurut ibu- ibu tersebut dia sudah berusaha untuk membuat anaknya mau makan, seperti membawa jalan- jalan, dan menyuapkan anaknya dengan makanan yang bervariasi. Menurut orang tua pemberian multi vitamin juga sudah pernah diberikan, namun anak tetap saja tidak memperlihatkan nafsu makan yang baik.

Saat ditanya apakah mereka sudah mencoba memberi madu, orang tua mengatakan belum pernah mencobanya. Saat peneliti menanyakan apakah ibu tahu kalau dari hasil penelitian bahwa pemberian madu pada anak dapat meningkatkan nafsu makan anak. Rata- rata ibu menjawabnya belum tahu, kemudian ibu terebut juga mengatakan kalau madu pada saat ini sudah jarang ditemui, khususnya madu asli, jadi ibu- ibu tersebut lebih cendrung pada multi vitamin, yang mudah didapat di apotek dan rumah obat. Keadaan fisik anak tampak kurus dan lesu serta pucat.

\section{METODE}

Adapun Tujuan dari penelitian ini adalah untuk melihat perbedaanterapi madu dan multivitamin terhadap kadar hemoglobin, albumin dan status nutrisi pada balita. Desain Penelitian ini adalah rancangan penelitian eksperimen sederhana (Randomized control Trial ), Sudigdo 2006. Populasai : adalah Semua Balita yang ada di Wilayah Kerja Puskesmas Nanggalo Kota Padang yaitu \pm 3497 orang.Sampel adalah semua balita yang mengalami susah makan dan berat badan tidak sesuai dengan umur ( $\mathrm{BB} / \mathrm{U}$ )kurang dari normal.Penelitian ini menggunakan analisis Wicoxon.Penelitian dilakukan dari bulan maret 2011 sampai September 2011. Sedangkan tempat penelitian adalah Wilayah Kerja Puskesma Nanggalo, Kota Padang.

\section{HASIL DAN PEMBAHASAN}

Data yang diperoleh dilakukan uji rerata General Linear Model dengan menggunakan pengukuran berulang ( reveated measure ). Namun setelah dilakukan uji normalitas data, ternyata sebaran, data tidak normal. Keadaan ini membuata uji rerata yang akan dilakukan batal, karena tidak memenuhi persyaratan yaitu sebaran data tidak normal. Sebagai alternative pengganti dari uji analisis pada penelitian ini dipakai uji Friedman. Setelah dilakukan uji Friedman, kedua kelompok mempunyai tingkat kemaknaan yang sama ( $\mathrm{p}<0.05$ ) berarti tidak terdapat perbedaan kelompok 1 dengan kelompok 2. 
Untuk mengetahui kelompok mana yang mempunyai perbedaan yang paling kuat, harus dilakukan uji Post Hoc. Alat uji post Hoc untuk uji Friedman adalah uji
Wilcoxon. Untuk melihat gambaran petrbedaan peningkatan hemoglobin dari kedua kelompok dipakai gambar reveated measure.

Tabel 1. Perbandingan Berat badan antara responden yang mendapat madu dan berat badan responden yang mendapat multivitamin pada anak balita diwilayah kerja Puskesmas Nanggalo Kota Padang.

\begin{tabular}{lllllll}
\hline \multicolumn{4}{l}{ Multi Vitamin } & \multicolumn{3}{l}{ Madu } \\
& Bb1 & Bb2 & Bb3 & Bb1 & Bb2 & Bb3 \\
\hline $\mathrm{N}$ & 30 & 30 & 30 & 30 & 30 & 30 \\
Mean & $\mathbf{1 1 . 4 3}$ & $\mathbf{1 1 . 4 7 0}$ & $\mathbf{1 1 . 5 1 0}$ & $\mathbf{1 0 . 5 9 7}$ & $\mathbf{1 0 . 6 9 7}$ & $\mathbf{1 0 . 8 2 7}$ \\
Std Dev & 2.3995 & 2.3830 & 2.2549 & 2.0737 & 2.0328 & 2.0172 \\
Min & 8.0 & 8.0 & 8.3 & 7.3 & 7.4 & 7.5 \\
Max & 16.0 & 16.0 & 16.8 & 15.0 & 15.0 & 15.0 \\
Nilai Z & -2.887 & -4.015 & -4.191 & -3.307 & -3.305 & -3.944 \\
\hline \multicolumn{1}{c}{ P } & \multicolumn{3}{c}{0.000} & & & \multicolumn{2}{c}{0.000} \\
\hline
\end{tabular}

Dari tabel 1, terlihat bahwa kedua kelompok memperlihatkan kenaikan dari nilai mean, standar deviasi, nilai minimal dan nilai maksimal. Dari uji statistic didapatkan nilai $\mathrm{P} 0.000$, berarti terdapat hubungan yang bermakna dari kedua kelompok. Untuk lebih jelas dapat dilihat pada grafik dibawah ini

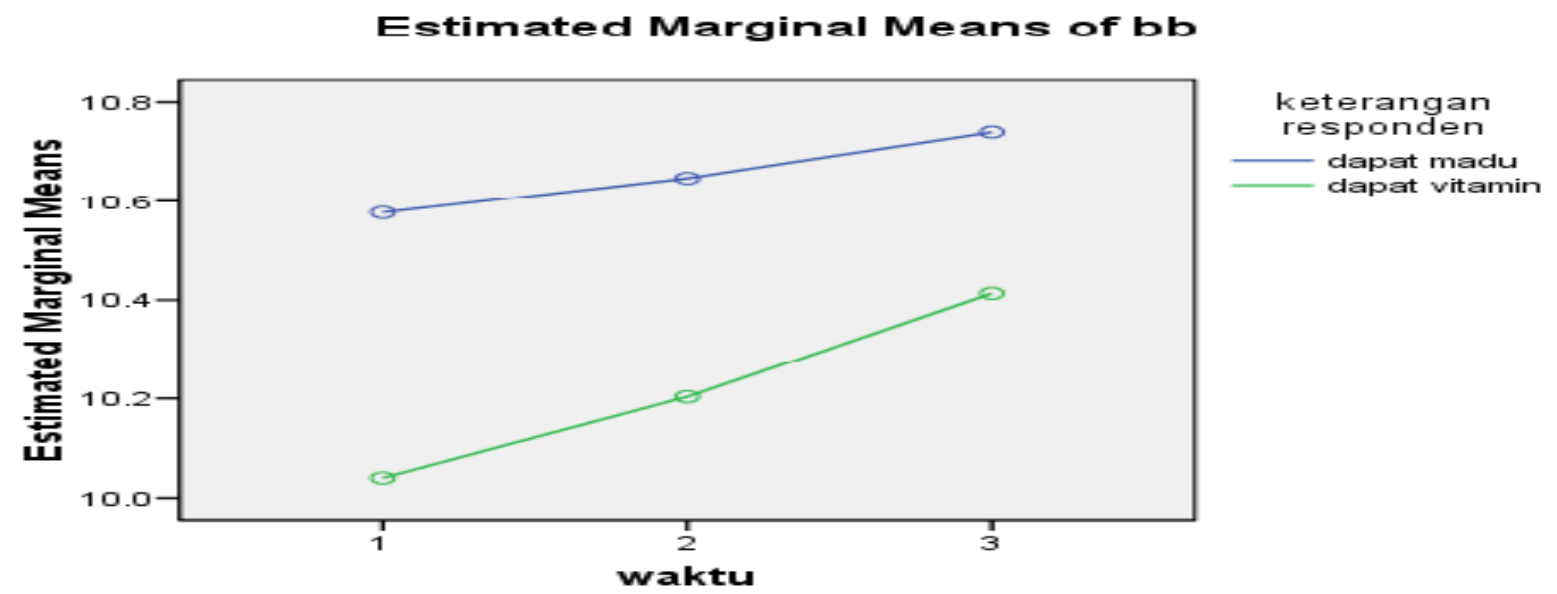

Tabel 2. Perbandingan Hemoglobin antara responden yang mendapat madu dan berat badan responden yang mendapat multivitamin pada anak balita diwilayah kerja Puskesmas Nanggalo Kota Padang.

\begin{tabular}{lllllll}
\hline & \multicolumn{5}{l}{ Multi Vitamin } & Madu \\
& $\mathrm{Hb} 1$ & $\mathrm{Hb} 2$ & $\mathrm{Hb} 3$ & $\mathrm{Hb} 1$ & $\mathrm{Hb} 2$ & $\mathrm{Hb3}$ \\
\hline $\mathrm{N}$ & 30 & 30 & 30 & 30 & 30 & 30 \\
Mean & $\mathbf{1 0 . 0 4 0}$ & $\mathbf{1 0 . 2 0 3}$ & $\mathbf{1 0 . 4 1 3}$ & $\mathbf{1 0 . 5 7 7}$ & $\mathbf{1 0 . 6 4 7}$ & $\mathbf{1 0 . 7 4 0}$ \\
Std Dev & 0.5519 & 0.4181 & 0.3329 & 0.7947 & 0.7389 & 0.6207 \\
Min & 9.0 & 9.3 & 9.5 & 9.3 & 9.6 & 9.8 \\
Max & 11.0 & 11.0 & 11.1 & 12.2 & 12.2 & 12.2 \\
Nilai Z & -3.771 & -4.240 & -4.481 & -3.402 & -3.429 & -3.519 \\
\hline $\mathrm{P}$ & 0.000 & & & 0.000 & & \\
\hline
\end{tabular}


Dari tabel 2 : Didapatkan nilai uji statistic P 0.000 , terdapat hub yang bermakna dari kedua kelompok. Namun kelompok responden yang mendapat intervensi multi vitamin memperlihatkan kenaikan dari nilai mean, standar deviasi, nilai minimal dan nilai maksimal yang paling baik. Untuk lebih jelas dapat dilihat pada grafik dibawah ini

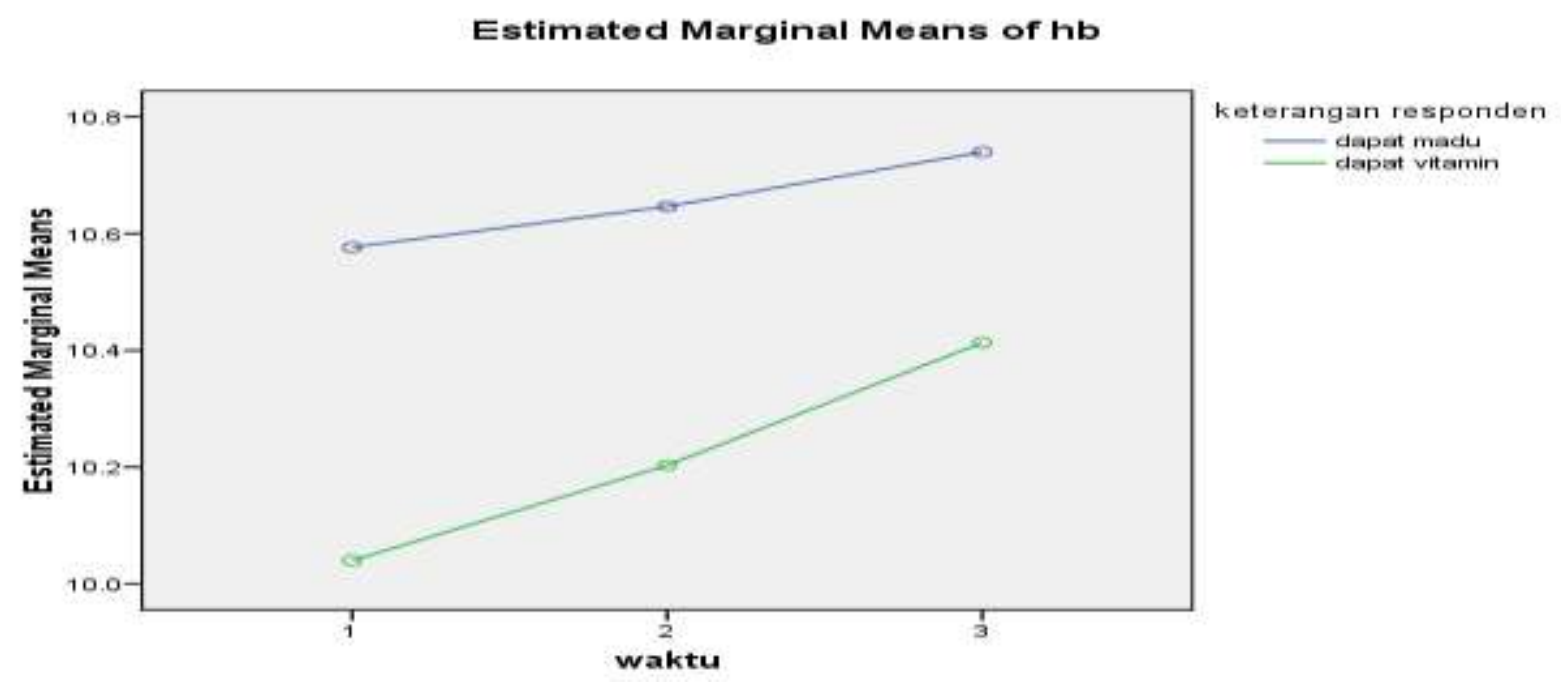

Tabel 3. Perbandingan Albumin antara responden yang mendapat madu dan berat badan responden yang mendapat multivitamin pada anak balita diwilayah kerja Puskesmas Nanggalo Kota Padang.

\begin{tabular}{lllllll}
\hline & \multicolumn{2}{l}{ Multi Vitamin } & \multicolumn{3}{l}{ Madu } \\
& Abm 1 & Abm 2 & Abm 3 & Abm 1 & Abm 2 & Abm 3 \\
\hline N & 30 & 30 & 30 & 30 & 30 & 30 \\
Mean & $\mathbf{3 . 6 8 0}$ & $\mathbf{3 . 7 1 0}$ & $\mathbf{3 . 7 6 7}$ & $\mathbf{3 . 7 4 0}$ & $\mathbf{3 . 7 6 0}$ & $\mathbf{3 . 7 9 0}$ \\
Std Dev & 0.4679 & 0.4436 & 0.4011 & 0.4056 & 0.3918 & 0.3418 \\
Min & 3.0 & 3.1 & 3.2 & 3.0 & 3.1 & 3.2 \\
Max & 4.8 & 4.8 & 4.8 & 4.7 & 4.7 & 4.7 \\
Nilai Z & -.3000 & -3.002 & -3.346 & -1.897 & -1.793 & -2.156 \\
\hline P & 0.000 & & & 0.000 & & \\
\hline
\end{tabular}

Dari tabel 3 , terlihat bahwa kedua kelompok memperlihatkan kenaikan dari nilai mean, standar deviasi, nilai minimal dan nilai maksimal. Dari uji statistic didapatkan nilai $\mathrm{P} \quad 0.000$, Namun kelompok yang mendapatkan multi vitamin meningkat lebih baik dari kelompok yang mendapat madu. Perbedaan tersebut dapat dilihat pada grafik didibawah ini 


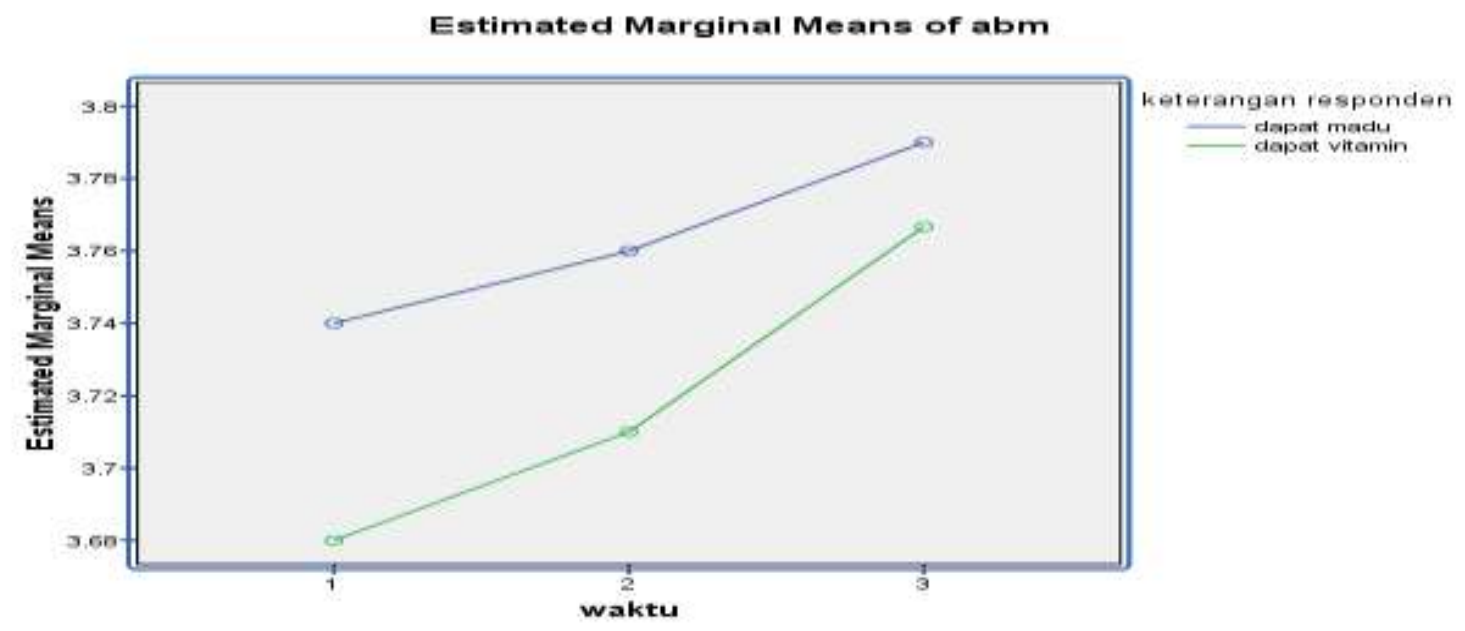

Tabel 4. Perbandingan status nutrisi antara responden yang mendapat madu dan responden yang mendapat multivitamin. pada anak balita diwilayah kerja Puskesmas Nanggalo Kota Padang.

\begin{tabular}{lllll}
\hline Status Nutrisi & $\begin{array}{l}\text { Multivitamin } \\
\text { Sebelum }\end{array}$ & sesudah & $\begin{array}{l}\text { Madu } \\
\text { sebelum }\end{array}$ & Sesudah \\
\hline Gizi lebih & 0 & 0 & 0 & 0 \\
Gizi baik & 8 & 16 & 10 & 17 \\
Gizi kurang & 22 & 14 & 20 & 13 \\
Gizi buruk & 0 & 0 & 0 & 0 \\
\hline Jumlah & 30 & 30 & 30 & 30 \\
\hline
\end{tabular}

Dari tabel 4, terlihat ada perubahan status nutrisi balita setelah mendapat intervensi, baik dengan vitamin, maupun dengan madu.

Dari hasil penelitian terlihat bahwa peningkatan berat badan pada kedua kelompok intervensi tampa meningkat dari pada sebelum diberi intervensi. Namun apabila dilihat dari Nilai $\mathrm{Z}$ hitungnya (-3.944) tampak kalau responden yang mendapat intervensi Multivitamin(-4.191 ) lebih baik dari responden yang mendapat intervensi Madu, keadaan ini jelas terlihat pada grafik. Banyak factor yang mempengaruhinya diantaranya adalah komposisi dan jumlah kadar mikronutrian dari multivitamin dan madu berlainan jumlahnya. Menurut Nursalam,(2001) Faktor internal yang mempengaruhi status gizi antara lain: adalah usia. Usia akan mempengaruhi kemampuan atau pengalaman yang dimiliki orang tua dalam pemberian nutrisi anak balita. Pada penelitian ini usia responden tidak homogen. Sedangkan menurut Suharjo dkk,(1986) bahwa kondisi fisik juga sangat mempengaruhi status gizi, kondisi fisik orang tua apabila dibandingkan dengan balita akan sangat berbeda, balita sedang membutuhkan gizi untuk tumbang, apabila ibu kurang mempunyai pengetahuan yang baik tentang kebutuhan gizi anaknya, akan sangat mempengaruhi sekali pada peningkatan berat badan anaknya.

Peningkatan albumin pada responden yang mendapat intervensi multi vitamin lebih baik kenaikannya apabila dibandingkan dengan albumin pada responden yang mendapat madu. Dari hasil penelitian dapat dilihat bahwa nilai $\mathrm{Z}$ hitung responden yang diintervensi multi vitamin (-3.346 )lebih baik dari $\mathrm{Z}$ hitung responden yang mendapat madu ( - 2.156 ) Dengan meningkatnya nilai albumin maka daya tahan tubuh balita akan bertambah 
baik . Peningkatan albumin juga mengindikasikan pungsi hati anak semakin baik. Dengan fungsi hati yang baik akan membuat anak bisa bertumbuh dan berkembang dengan baik. Albumin merupakan jenis protein terbanyak di dalam plasma yang mencapai kadar 60 persen. Protein yang larut dalam air dan mengendap pada pemanasan itu merupakan salah satu konstituen utama tubuh. Albumin juga dipakai sebagai tes pembantu dalam penilaian fungsi ginjal dan saluran cerna. Albumin mengandung 584 asam amino, golongan protein ini paling banyak dijumpai pada telur (albumin telur), darah (albumin serum), dalam susu (laktalbumin). Berat molekul albumin plasma manusia 69.000, albumin telur 44.000, dalam daging mamalia 63.000 .

Dari hasil penelitian didapat kalau sebenarnya kedua terapi yang telah diberikan mempunyai efek yang baik untuk meningkatkan Berat badan, hemoglobin dan albumin, namun setelah dilihat lebih jauh lagi, melalui analisa statistic efek dari pemberian multi vitamin ternyata lebih baik dari efek madu. Hal ini disebabkan oleh multi vitamin memang telah diramu untuk memenuhi semua kebutuhan balita. Tidak sama dengan madu yang saat ini sulit mencari madu yang benar- benar asli. Dengan tidak murninya madu membuat kandungan gizi yang terdapat didalamnya kurang sesuai dengan kebutuhan balita, sehingga kebutuhan untuk balita belum bisa terpenuhi semuanya.

\section{KESIMPULAN DAN SARAN}

Terapi madu maupun terapi multi vitamin dapat meningkatkan berat badan hemoglobin dan albumin pada balita. Namun terapi multi vitamin lebih baik dari pada terapi madu dalam meningkatkan berat badan, kadar hemoglobin serta kadar albumin pada balita diwilayah kerja Puskesmas naggal Kota Padang tahun 2011

Dianjurkan kepada petugas kesehatan untuk memberikan penyuluhan kepada masyarakat agar balita diberi minum multi vitamin guna melengkapi kebutuhan untuk tumbang balitanya karena mudah didapat dengan harga yang terjangkau oleh masyarakat.

\section{DAFTAR PUSTAKA}

Almatsier,S. 2001.Prinsip Dasar Ilmu Gizi.Jakarta.Gramedia Pustaka Utama,

Alimul Hidayat2005. Pengantar Ilmu Keperawatan Anak. Jakarta : Salemba Medika.

Golden M.H.N. 2001. Severe malnutrition. Dalam : (Golden MHN ed). Childhood Malnutrition : Its consequences and management. What is the etiology of kuashiorkor? Surakarta : Joint symposium between Departement of Nutrition \& Departement of Paediatrics Faculty of Medicine, Sebelas Maret University and the Centre for Human Nutrition, University of Sheffielob UK, 1278-1296.

Puone T, Sanders D, Chopra M . 2001. Evaluating the Clinical Management of Severely Malnourished Children. A Study of Two Rural District Hospital. Afr Med J 22 : 137-141.

Whaley and Wong. 2009. Nursing Care infants and children. Fourth Edition, Mosby Year Book, Toronto Canada.

Sutjiningsih. 2009. Tumbuh Kembang Anak, EGC. Jakarta.

Dinkes Kota Padang tahun 2010. Profil Kesehatan Kota Padang Tahun 2010 